\title{
Translating Reduplication in Some Selected Verses of the Glorious Qur'an into English
}

\author{
Assistant Professor Ibtihal M. Al Tameemi/PhD \\ Department of English /College of Languages/University of Baghdad \\ Email: docibtihal@gmail.com
}

Received:29/10/2019

Accepted:1/12/2019

This work is licensed under a Creative Commons Attribution 4.0 International License

\begin{abstract}
Reduplication can be defined as a morphological process where the root or stem of a word (or part of it) is repeated exactly or with a slight change. It can be found in many world languages with various types and uses. This paper investigates reduplication in terms of phonology, morphology, and semantics in some selected verses of the Glorious Qur'an concerning its kinds and its translation into English. The main problem of the present research is concerned with the way of translating reduplication concerning the Glorious Quran. Different interpretations of reduplication are adopted to show the efficiency and the rhetorical functions of these forms. More specifically, four translations of Pickthall, Yusuf Ali, Shakir, and Arberry are examined to find the strategies and methods used to translate reduplication accurately and appropriately. It is concluded that some translators succeeded in translating reduplication, whereas others could maintain neither the functions nor the impacts of such forms in English. However, it is challenging to render reduplication phonologically and morphologically into English due to the eloquence and inimitability of the Glorious Qur'an.
\end{abstract}

Keywords: Glorious Qur'an, morphology, phonology, reduplication, translation 
ترجمة التضعيف في بعض السورالمختارة من القرآن الكريم الى اللغة الانكليزية

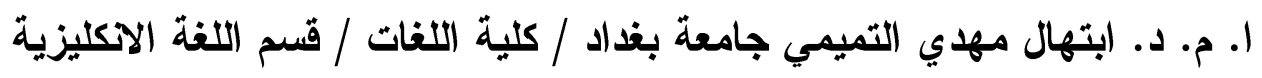
ايميل :

المستخلص :

يُعرّف التضعيف على انه عملية صرفية ، إذ يكرر الجذر او جزء من الكلمة بصورة تامسـة

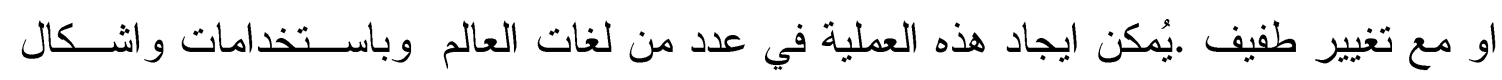
متتوّعة . مع نينر

يستقصي هذا البحث التضعيف من الناحية الفونولوجية (الصوتية ) ، الصرفية و الدلالية في

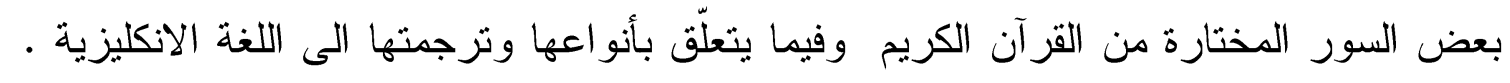

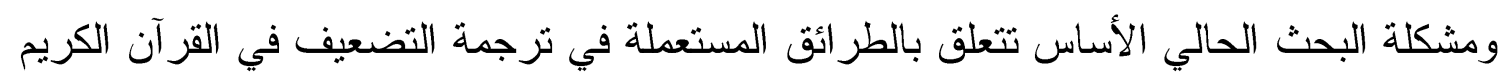

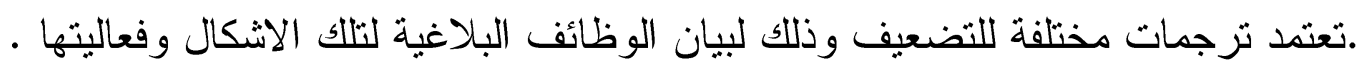

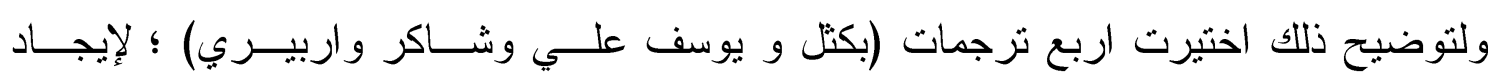

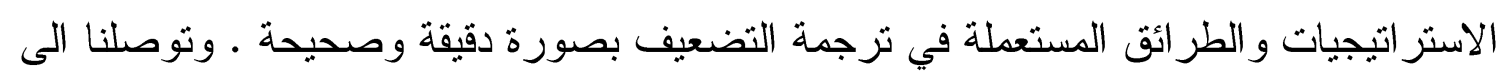

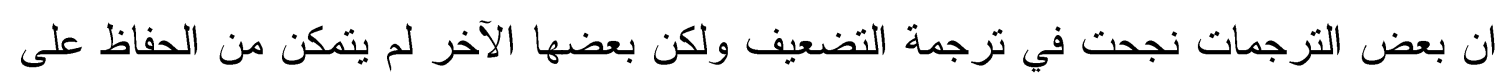

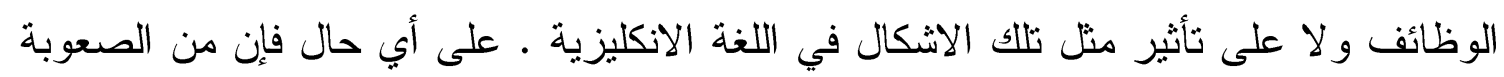

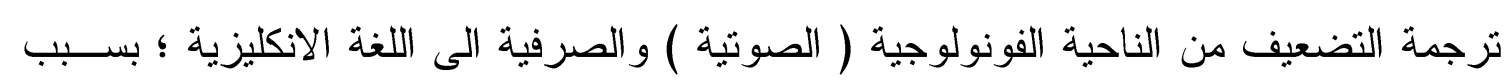
اعجاز القرآن الكريم وبلاغته.

الكلمات المفتاحية : النزرجة ، التضعيف ، القران الكريم ، النظام الصوتي، علم الصرف. 


\section{Introduction}

Reduplication has been known widely among the world's languages. According to Sapir, reduplication is one of six main types that may affect verbs and adjectives and usually results in morphological and semantic changes of the word or base.

It is considered one of the linguistic phenomena in the Qur'anic text that plays a distinctive rhetorical role which eliminates excess meanings and enhances what is necessary. This paper is concerned mainly with the phonological, morphological, and semantic aspects of reduplication in some selected verses of the Glorious Qur'an and how to render them into English. Four translations among the best-known translations of the Glorious Qur'an are chosen for analysis and assessment. Besides, the different types and functions of reduplication are discussed.

\section{Review of Literature}

Reduplication can be described morphologically as well as phonologically. From the morphological point of view, it is a reduplication of linguistic constituents ( $\mathrm{i}$.e. words, stems roots) (Stageberg,1981, p.727). More specifically, for Katamba (1999, p.220) reduplication is a

"word-formation process by which a prefix is created by repeating the first consonant and vowel of a base." Thus, reduplication indicates the recurrence of a morpheme completely like( tick-tick) or partially like (zigzag) (Crystal, 2003, p. 391, Nadarajan, 2006, p.39 and Katamba \& Stonham, 2006,p. 180). Various conventions and terms of reduplication appeared including cloning, doubling, duplication, repetition, reinforcement, reiteration, recurrence or repetition, but it is distinguished in specific characteristics from others in that:

A- It is a mere morphological formation.

b- Its broader structure deals with the repetition of roots, stems, and affixes or individual words.

c- Its repetitive elements are often juxtaposed

(Gil, 2005,p. 33-37)

On the other hand, reduplication is often described phonologically in one of the two different ways: either (a) as reduplicated segments (sequences of consonants /vowels) or (b) as reduplicated prosodic units.

Accordingly, reduplication is interesting theoretically since it requires the interface between phonology and morphology. In reduplication, the base is a word (or part of the word) that is often copied. The reduplicated element is called the reduplicant (RED) or $(\mathrm{R})$, and most often repeated only once as in you are a sic

$k$, sick man or you're sick.

To sum up, reduplication is among the word-formation processes found in English, and it is one of the six main kinds of grammatical processes. It is used with various forms to achieve various purposes: morphological, semantic, phonological, and syntactic.(Crystal ,2006,p.228)

\section{Types of Reduplication}

Haspelmath (2002,p.24) classifies reduplication into two types: pre-reduplication (premodification) and post- reduplication (post-modification), which imply whether the repeated or copied element comes before or after the base. Diagram (1) below illustrates these types: 


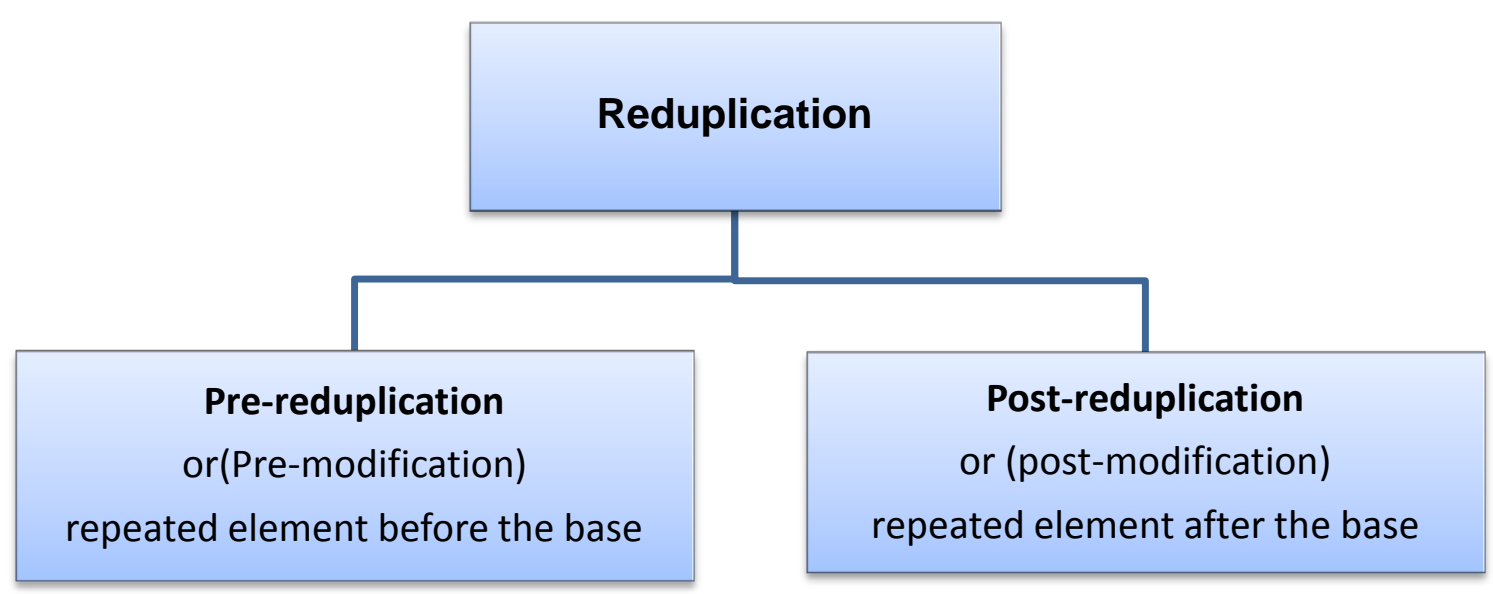

Diagram (1) Types of Reduplication according to Haspelmath (2002)

The first three types constitute the conventional aspect of reduplication. On the other hand, Inkelas \& Zoll (2005) extend the three traditional types of reduplication to include two items as:

a. Partial reduplication (repetition of a phonologically defined sub-constituent of a word, with potential concomitant phonological modifications). Repeating part of a word to produce a variety of forms. In partial reduplication, there is no clear-cut between morphological and phonetic boundary. Therefore sound change is only considered (Spencer and Zwicky,2001, p.132 and Nadarajan,2006,p.42)

b. Total reduplication (repetition of a root, stem or word, with minimal or no phonological modifications).

c. Echo reduplication (reduplication of a word, with the replacement of the onset or, sometimes, vocalism or internal material in one copy).Echoism is a distinctive form that includes repetition of words for aesthetic or expressive effect. It contains primary onomatopoeia and secondary onomatopoeia. In primary onomatopoeia, there is an attempt to direct imitation of naturally occurring sounds in sound symbolism or natural correspondence between sound and sense.

d. Synonym reduplication (the juxtaposition of two roots, stems or words which are synonymous, antonymous or closely semantically related).

e. Syntactic doubling (in which a single word or constituent is mandated to occur twice in the same syntactic construction, often with obligatory intervening material)

\section{Functions of Reduplication}

Reduplication serves a wide variety of functions. These function range over the standard morphological functions of derivation and inflection. Reduplication can also serve as a phonological concomitant of affixation and even merely as a semantically contentless structural repair.

Dineen, on the other hand, believes that reduplication is used with various forms to achieve multiple purposes: lexical, morphological, and grammatical. (1996, p.228).

Furthermore, the functions of reduplication can be considered rhetorical as well as cohesive. Content can be reiterated in a paraphrased form or alternative lexical forms (near-synonyms), and meaning is specific to the context (Wang, 2005). 


\section{Research Methodology}

The current study investigates reduplication which is considered one of the most profound linguistic phenomena in the Qur'anic text and plays a distinctive rhetorical role that eliminates excess meanings and enhances what is necessary. Some verses have been chosen from the Glorious Quran that includes reduplication whether totally or partially.

\subsection{Data Collection}

It seems that there is an urgent need to review and assess the English translations of the Glorious Qur'an to identify the differences of these translations as well as to find out whether they are appropriate and accurate and then to suggest other translations that may contribute to improving the future renditions of the Glorious Quran. The present study is limited to six verses of the Glorious Quran that represent reduplication both totally and partially. Four translations of these verses are adopted; namely, those by Pickthall, Yusuf Ali ,Shakir and Arberry.

\section{2 Data Analysis and Discussion}

The selected data of this study consist of six verses of the Glorious Quran that are chosen to show two types of reduplication and then are analyzed phonologically and morphologically with an emphasis on the phonological aspect to show its impact and find out whether it is rendered appropriately and accurately.

\section{Examples of Total (or Full) Reduplication in the Glorious Qur'an Sample (1) Sūrat yūsuf (Joseph)}
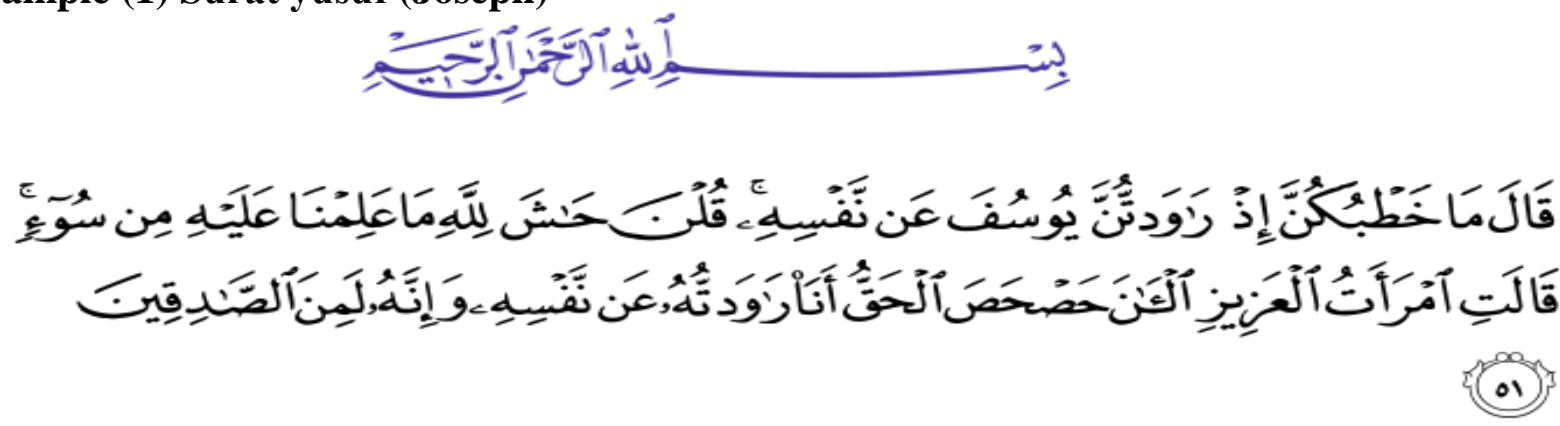

Pickthall: He (the king) (then sent for those women and) said: What happened when ye asked an evil act of Joseph? They answered: Allah Blameless! We know no evil of him. Said the wife of the ruler: Now the truth is out. I asked of him an evil act, and he is sure of the truthful.

Yusuf Ali: (The king) said (to the ladies): "What was your affair when ye did seek to seduce Joseph from his (true) self?" The ladies said: "Allah preserves us! No evil know we against him!" Said the 'Aziz's wife: "Now is the truth manifest (to all): it was I who sought to seduce him from his (true) self: He is indeed of those who are (ever) true (and virtuous).

Shakir: He said: How was your affair when you sought Yusuf to yield himself (to you)? They said: Remote is Allah (from imperfection), we knew of no evil on his part. The 
chief's wife said: Now has the truth become established: I sought him to yield himself (to me), and he is most surely of the truthful ones.

Arberry: 'What was your business, women,' he said, 'when you solicited Joseph?' 'God save us!' they said. 'We know no evil against him.' The Governor's wife said, 'Now the truth is at last discovered; I solicited him; he is a truthful man.

It is self-evident that all the translators could not translate the verb حَصَحَadequately.

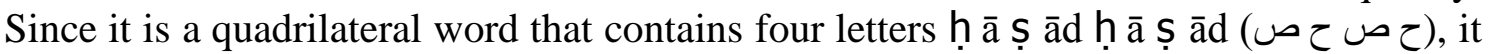
represents full reduplication and should be transliterated as " ḥ aṣ ḥ as a" to maintain its impact besides its interpretation or content. Phonologically, none of the translators succeeded in translating the verb حصحص"," but semantically they translated the verb into its near equivalent.

Furthermore, one of the characteristics of sound 'Haa' حاء is whisper and friction and is characterized by weak speech because much is confused with the sound 'ha' As for the sound ' Sad,' it is one of the of saffron sounds and has no glorious equivalent. It has a clear whistle and sharp.

Sample (2) sūrat l-zalzalah (The Earthquake), Ayah (1)

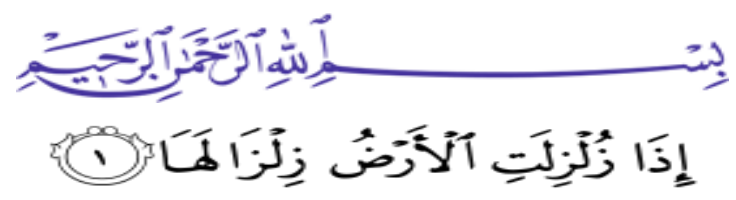

Pickthall: When Earth is shaken with her (final) earthquake

Yusuf Ali: When the earth is shaken to her (utmost) convulsion,

Shakir: When the earth is shaken with her (violent) shaking,

Arberry : When the earth is shaken with a mighty shaking

It can be noticed that the four translators did not recognize the verb "زُلز لت where the phonological segment " Zul" is reduplicated. In other words, the quadriliteral root zāy lām zāy lām $(J)$ ) occurs in the ayah as mentioned above that represents a sound of shaking and from which the noun zil'zālaha (jلزَالها) is derived. Although the four versions are entirely appropriate and acceptable semantically, they are phonologically and morphologically inappropriate and nonequivalent. Therefore, it is suggested to transliterate the verb "زئزل into "zul'zilati" to keep the form of the verb which has an impact on the reader or listener and then translates it into "is shaken" to maintain its content or meaning.

Sample (3) Sūrat l-fajr (The Dawn), Ayah $(21,22)$

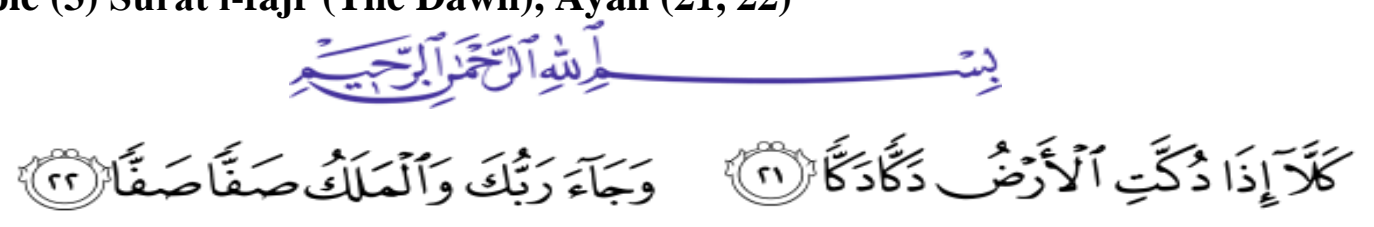

Pickthall: Nay, but when the earth is ground to atoms, grinding, grinding, And thy Lord shall come with angels, rank on rank,

Yusuf Ali: Nay! When the earth is pounded to powder, And thy Lord cometh, and His angels, rank upon rank,

Shakir: Nay! when the earth is made to crumble to pieces, And your Lord comes and (also) the angels in ranks, 
Arberry: No, indeed! When the earth is ground to powder, and thy Lord comes, and the angels rank on rank,

In this verse, what distinguishes the reduplicants " دكأ dakka and "صفأ affan is that it is balanced in the semantics of its connotations that suggest greatness and majesty. But, if we stop at the word "dakan" it means the global coup that occurs on the Day of Resurrection, and contains two sounds (consonants) that indicate the force whereas, in this context, the pronunciation of the sound Kaff must be harsh. Nevertheless, Pickthall succeeded in rendering both reduplicants in terms of meaning and form

Examples of Partial Reduplication in the Glorious Qur'an

Sample (1) Sūrat l-nāzi $\square \bar{a} t$ (Those who Pull Out)

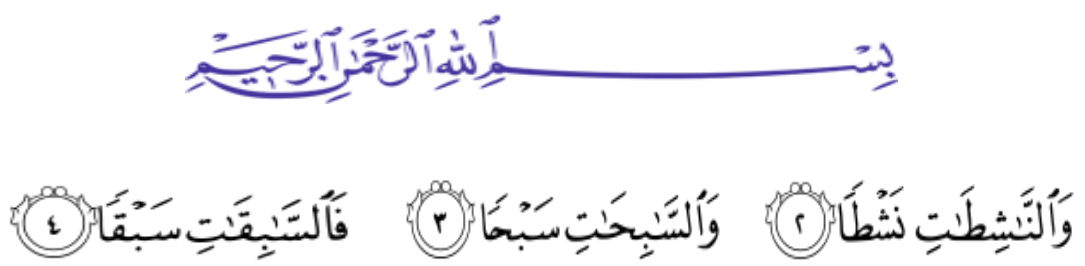

Pickthall: By those who drag forth to destruction, by the lone stars floating, by the angels hastening.

Yusuf Ali: By the (angels) who tear out (the souls of the wicked) with violence; and by those who glide along (on errands of mercy), Then press forward as in a race.

Shakir: I swear by the angels who violently pull out the souls of the wicked, And by those who float in space, Then those who are foremost going ahead.

Arberry: By those that pluck out vehemently, by those that swim serenely, and those that outstrip suddenly.

Reduplication is commonly used to derive word classes and tense- aspects. In this sample, the accusatives are derived from the nominatives by using reduplication partially. What is noted in this sample is that partial reduplication is based on diversity formed from selected sounds to monitor acoustic dimensions? This coloration combined the nominatives with accusatives taking into consideration the semantic consequences. However, the translators focused on the content of these words and ignored their forms where eloquence and beauty are characteristics of such type of structures. To achieve the purpose of such structures in the Glorious Qur'an, it is suggested to transliterate these forms into "wal-nāshit āti nashṭ an," "wal-sābiḥ āti sabḥ an," "fal-sābiqāti sabqan" with their appropriate meaning or content.

Sample (2) Sūrat l-humazah (The Slanderer)/ Ayah (6)

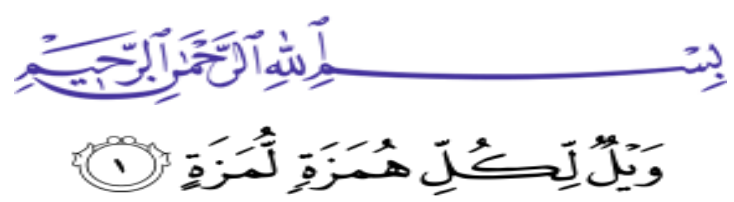

Pickthall: Woe unto every slandering traducer,

Yusuf Ali: Woe to every (kind of) scandal-monger and-backbiter,

Shakir: Woe to every slanderer, defamer,

Arberry: Woe unto every backbiter, slanderer, 
It is observed that none of those mentioned above versions are equivalent in terms of form to the original text. The four translators failed to transfer the partial reduplication

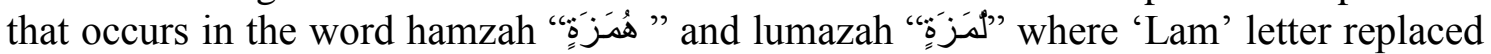
'haa' letter to get a new lexical item with a new meaning. In other words, phonologically

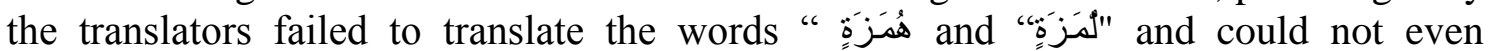

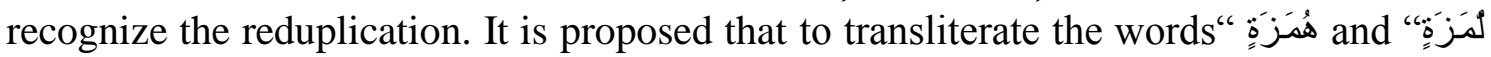
to maintain its aesthetic and expressive impact with its content.

\section{Sample (3) Sūrat l-inshiqāq (The Splitting Asunder)/ Ayah (6)}

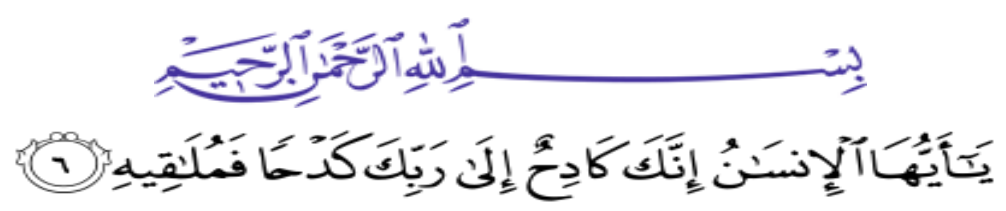

Pickthall: Thou, verily, O man, art working toward thy Lord a work which thou wilt meet (in His presence).

Yusuf Ali: O thou, man! Verily thou art ever toiling on towards thy Lord- painfully toiling,- but thou shalt meet Him.

Shakir: O, man! Surely you must strive (to attain) to your Lord, $\underline{\text { a hard striving until }}$ you meet Him.

Arberry: O Man! Thou art laboring unto thy Lord laboriously, and thou shalt encounter Him.

In the above verse, Almighty Allah repeated the word "kadh" in two different versions, but the sounds are familiar. The effort to choose the correct pronunciation to express the place is difficult. The composition of the sounds between the looseness and intensity, and ignorance and whispering earned a quiet rhythm inspired by all the implications.Moreover, this type of reduplication which is considered partial reflects the beauty of the Qur'anic text where the diversity of the formula of the nominative " كادح" and the accusative "كدحا" is used. Accordingly, the four translators could not recognize the aesthetic and expressive impact of the sounds of these words and failed to render it into English. Therefore, phonologically, the versions are not accurate and equivalent, but morphologically it seems that all the translators recognize the form of the words "

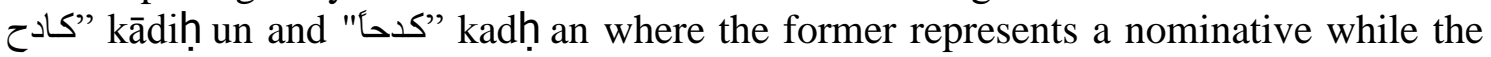
latter indicates an accusative. Nevertheless, semantically all the translators try to give an equivalent 


\section{Conclusion}

Reduplication is a phenomenon characterized by the Quranic text in places required by the context to achieve specific purposes and should be maintained because of its impact in strengthening the relationship between sound and significance.

The Glorious Qura'an employs repeated sound to determine the intended significance. Also, the repeated sound that is characterized by the qualities of distress and ignorance indicates intimidation.

In the light of the discussions carried in this paper, it is found that the translation of the Glorious Qur'an in relation to reduplication should be carried out by a team of scholars who experienced different branches of knowledge related to the Glorious Qur'an and know thoroughly and fluently both Arabic language as the language of the Quran (SL) and its complex grammar as well as English language (TL).

However, the literal translation approach is inappropriate because the Glorious Qur'an cannot be translated literally, and the communicative one may create a loss of meaning. Thus, to accurately deliver the complexities of the message conveyed in the Glorious Qur'an it is recommended to transliterate some of the forms such as reduplication (whether full or partial ) to preserve the aesthetic and rhetorical aspects of the Quranic text, and the semantic translation should be displayed as well. 


\section{References}

Ali, A. Y. (1989). The Holy Quraan: Text Translation and Commentary. Kuwait. That Es-Salasil printing, Second Edition.

Arberry, A. J. (1991) The Koran Interpreted. Oxford: Oxford University Press.

Crystal, D. (2003) A Dictionary of Linguistics and Phonetics.Oxford: Oxford University Press.

Dineen, F. P. (1996). An Introduction to General Linguistics. New York: Holt, Rinehart, and Winston

Gil, D.(2005).From Repetition to Reduplication in Riau Indonesian. Hurch

Haspelmath, M. (2002). Understanding Morphology. London: Arnold.

Inkelas, S., and C. Zoll. (2005). Reduplication: doubling in morphology. Cambridge: Cambridge University Press.

Katamba, F., and John S. (2006). Modern Linguistics: Morphology. Second edition London: Macmillan Press Ltd.,

Nadarajan, Sh. (2006). A Crosslinguistic Study of Reduplication. University of Arizona, Vol. 13, Arezona working papers in SLAT.

Pickthall, M. M. The Meaning of the Glorious Koran. New York: New American Library, n.d.

Spenser, A. and Zwicky,A. M.(2001). The Handbook of Morphology. USA: Blackwell Publishing Ltd.

Stageberg, N. C.(1981). An Introductory English Grammar. USA: Holt, Rinehart, and Winston, Inc.

The Quranic Arabic Corpus -Translation available on http://corpus.quran.com/translation.jsp? chapter $=79 \&$ verse $=1$

Wang, S. P. (2005). "Corpus-based approaches and discourse analysis concerning reduplication and repetition": Journal of Pragmatics. 37,505-540.

Yule, G.( 2006) The Study of Language. $3^{\text {rd }}$ ed. Cambridge: CUP. 